\title{
THE PLIGHT OF THE BLACK RETARDED CHILD: HOW THE NURSE CAN ASSIST
}

This article is based on a paper presented by an occupational therapist, Miss Yvonne Kauril, at a symposium entitled “THE PLIGHT OF THE BLACK RETARDED CHILD” held in Johannesburg in 1979. Miss Kauril is a member of the Advisory Board of Self-Development Communities for the Retarded.

While modern trends emphasise the need to educate and train the retarded child and adult, many aspects of mental retardation remain in the medical realm. There is therefore much that can be done by the medical and paramedical worker to assist the retarded child and its family; not only from the point of view of health but even to achieve some degree of education and/or training. The emphasis here is on the Black retarded child.

From figures provided by the S.A. National Council for Mental Health there are upward of 50000 Black mentally retarded children in South Africa. Facilities for these children are few and far between. Half a dozen or so day care centres run by the Mental Health Society throughout the country constitute the only real facility which these children enjoy. Each centre, however, can only cater for a handful. Mainly the children are kept at home, abandoned by their families in institutions or sent to ordinary schools.

While the latter course of action seems designed to impose hardships on both the child and the teacher, the experiences of an occupational therapist at Baragwanath Hospital indicate that this need not be the case. The nurse can be of great assistance to both the child and the teacher.

Provision for the education and training of the Black retarded child was included for the first time in legislation recently passed (Education and Training Act 1979) as was the provision of medical, paramedical and therapeutic treatment. It is extremely likely, therefore, that more contact than ever will be being made by members of the nursing profession with mentally retarded children.

Examination of some of the points made by Miss Yvonne Kauril, an occupational therapist at Baragwanath Hospital, in an address to a symposium in Johannesburg, points the way to how members of the medical profession and nurses in particular can participate in improving the quality of life for the retarded child.

The symposium, entitled "The Plight Of The Black Retarded Child" was attended by some 200 teachers, nurses, social workers and school principals. It was organised by the Self-Development Communities of the Retarded, a group operating in Johannesburg, Durban and Cape Town.

There are two main types of retardation. Both are found in varying degree - mild to severe. The inherent type results from slow or terminated neurological maturation i.e. the rate at which the brain develops, is retarded, or has stopped. The second, or acquired type, means the potential for normal development was there at birth. At some time during the child's life, adverse factors or circumstances occurred which prevented him from following the normal pattern of development and realising his full potential.

It is the function of the medical and rehabilitation team to assess the nature of the retardation. Based on this, the team then assists the family to direct the course of the child's life.

In the handling of the acquired type of retardation the teacher must know (1) exactly what the child's disability is and (2) exactly what the child's ability is.

As experience revealed that many children were struggling with a handicap underlying their academic difficulty it is here that the medical or paramedical worker can be of tremendous assistance to the teacher, either directly or through the parent. By being advised as to points (1) and (2) above the teacher can adjust the teaching approach to suit the needs of the child.

The demands placed upon a child by schooling make it important that he is functioning as an integrated whole. A brief look is taken at some of these demands:

- ability to cope with fine dexterity required in writing

- independent mobility to get around the school

- ability to see what is written on the blackboard

- ability to hear the teacher above all the other noise

- ability to concentrate in an environment full of distraction.

- ability to understand and remember

- ability to express oneself

- self-confidence and ability to cope in a competitive and socially demanding situation.

At Baragwanath cerebral palsy clinic, school readiness is assessed by the pooling of information from different specialists: neurologist, physiotherapist, speech therapist, occupational therapist and nursing staff: when available, a psychologist. Screening for school readiness, however, is generally not found.

As far as possible use was made of normal schools. This depended upon the interest and co-operation of principals and teachers. In $99 \%$ of cases this was willingly given. Experiments with plus/minus 20 children 
revealed that normal schools can be used where children have minimal learning problems - whether of a global or specific nature - provided the teacher was fully informed and assisted where necessary with practical advice, e.g. where to position the child in the classroom, physical alterations such as size of book or pen- what sort of input should be emphasised and so on.

By providing information of this type, and other data obtained by examination and observation of the child by someone medically qualified and equipped to assess its disabilities, the task of the teacher can be made easier.

In this way much can be done to alleviate the plight of the retarded child and to contribute in no small measure to its acquiring suitable education and/or training. This will lead in turn to its eventual integration into the community as a reasonably healthy, contributing individual.
PRINCIPLES AND PRACTICE OF NURSING deur V. Henderson en G. Nite, (MacMillan Co., Inc., New York, Prys: R32,15 plus A.V.B.).

Hierdie boek bevat vyf afdelings:

1. Dit gaan oor die plek van verpleging in die gesondheidsdiens en bespreek o.a. die verpleegproses en die onderliggende teorie. Verpleegonderrig word ook bespreek in die tipiese Hendersonstyl.

2. Handel oor die rol van die verpleegster in gesondheidsevaluasie en die beplanning van verpleegsorg. Dit word baie deeglik behandel en laat aan die verpleegster niks te raaie oor wat bv. alles gedoen moet word wanneer 'n pasiënt opgeneem word nie.

3. Gaan oor die grondslae van verpleging en hoe ander gehelp moet word om in hulle eie basiese behoeftes te voorsien. Alles word volledig bespreek wat deel uitmaak van die mens se daaglikse bestaan en hoe hy self verantwoordelikheid moet neem vir sy eie gesondheid.

4. Handel oor terapeutiese bedrewenhede met die klem op die rol van die verpleegster en op verpleging.

5. Handel oor algemene probleme en simptomatiese verpleging daarvan. Dit dui aan hoe die basiese elementêre verpleegsorg aangepas kan word by abnormaliteite bv. van asemhaling, eliminasie en al die aktiwiteite van die daaglikse lewe.

Oor die algemeen beskou is hierdie 'n boek wat werklik handel oor verpleging en dit is nie 'n halfgebakte mediese boek met terloopse verwysings na verpleegsorg nie. Dit is baie afgestemd op die ekspressiewe funksie van die verpleegster, alhoewel die instrumentele funksie nie verwaarloos word nie. Die pasiënt of kliënt word ook deurgaans in totaliteit beskou en nooit geobjektiveer nie.

Hierdie boek is deur verpleegsters vir verpleegsters geskryf en sal ' $n$ waardige en geregverdige aanwins wees vir elke biblioteek, dosent en praktiserende verpleegster, van watter hiërargie ookal.

A.M. PRELLER 